\title{
Hierarchical assemblages of citizenship and belonging: The pedestrian speech acts of British Gujarati Indian walkers
}

\begin{abstract}
The 2018 Windrush generation controversy, made public state-induced hostilities towards African Caribbean citizens of the nation. However, this is not a new phenomenon. The state's de-humanising treatment of racial and ethnic minority migrant settlers, has a much longer history. I make visible this history by exploring the informal walking pastimes of five, married, British Gujarati Indian couples, many of whom, like other South Asian migrants, arrived in England during the 1960s and 1970s. Using the notion of pedestrian speech acts (de Certeau, 1984), I explore the relationship between race, urban multiculture, citizenship and belonging. The findings signal how public and state discourses are mobilised by these walkers to repeatedly invoke their citizenship, mainly by Othering Eastern European communities as well as in terms of what I have called hierarchical assemblages of citizenship and belonging, elucidating the dynamic complexities of racial, ethnic, religious, caste, class, gender, and generational unities and tensions.
\end{abstract}

\section{Keywords:}

Belonging; Citizenship; Gender; Gujarati Indians; Informal Leisure; Pedestrianised Speech Acts; Racism; Researching with/ on family; Multiculturalism; and Walking Methodologies.

\section{Author:}

Dr. Aarti Ratna, Solent University, Southampton (U.K.)

\section{Corresponding author details:}

Dr. Aarti Ratna, School of Sport, Health and Social Sciences, East Park Terrace Campus, Southampton, Hampshire, SO14 0YN. Email: aarti.ratna@solent.ac.uk

\section{Introduction}


This article mobilises de Certeau's (1984) concept of pedestrian speech acts, making visible how city-spaces are read, lived, and made by long-term first-generation citizens, especially those who are racialised as unwanted "migrants" (Bhambra, 2018). Their precarious position has been painfully apparent in recent times, through the state's historic and on-going mistreatment of the Windrush generation: that is, deporting Caribbean people who are British back to a "home" they no longer know or have never known (Bhambra, 2018). This precarious position though is not just the experience of the Windrush generation: the "hostile" politics of citizenship, belonging and exclusion affects a range of racial and ethnic groups as well as undocumented migrants, asylum-seekers and refugees (Jones et al, 2017). Claiming citizenship within and between different racial and ethnic communities, creates entangled and fluctuating webs of belonging and non-belonging (for example, see Ratna, 2014). I suggest that these complexities are not just reflective of new hierarchies of racial belonging (Back, Sinha and Bryan, 2016) but also, that they are inextricably tied to shifting and complex assemblages of power (Puar, 2007; Yuval-Davis, Wemyss and Cassidy, 2018). In this article, focusing upon Gujarati Indians' informal walking pastimes, I demonstrate how they as first generation British citizens (in their 60s at the time of the research) continue to negotiate belonging vis-à-vis other racial and ethnic groups as well as popular discourses which simultaneously position them as model minority citizens and disloyal, self-segregating and potentially terrorist members of the nation. I, therefore, elucidate how they - as individuals and a group - through interconnected signifiers of caste, class, gender, generation, and religious unities and tensions, stake claims to their spaces of "home", neighbourhood and nation, (re)constructing new and shifting hierarchical assemblages of citizenship and belonging in the process.

Building upon studies of informal leisure (Watson and Ratna, 2011; Thangaraj et al, 2018) and more recent sociological analyses of urban multi-culture (e.g. Jackson, 2018; Neal et al, 2018; Back et al, 2018; Valluvan, 2016; Yuval-Davis, Wemyss and Cassidy, 2018), I focus upon walking not only as a leisure pastime but also as a methodological approach, using pedestrian speech acts to explore "small" and "big" constructions and re/presentations of cityspaces. I also add to current debates about walking methodologies (see Bates and Rhys-Taylor, 2018) through a novel approach to constructing knowledge for, about, and with, familial relations. I suggest that working through the ethics, politics and dynamics of familial-based research is challenging, but that this does not necessarily preclude it from illuminating how 
hierarchical assemblages of citizenship and belonging - discursively and materially - are (re)constructed through everyday life and leisure. To elucidate the key arguments, I first introduce the spatial focus of the article: that is, London. Next, I refer to pedestrian speech acts to explore "small" and "big" analyses of city-spaces as well as the relationship between structural inequities and urban multiculture. After positioning my walking methodological approach, and familial praxis, the findings are developed through three inter-related parts: 1) an exploration of some of the Gujarati Indian walkers' tolerant attitude towards different migrant communities; 2) how other Gujarati Indian walkers, contrastingly, have developed an intolerant and/or more ambiguous attitude towards Eastern European communities; and 3) how the contradictory and shifting attitudes of the British Gujarati Indian walkers, towards migrant "Others", is also linked to intra-racial, ethnic, religious, caste, class, gender, and generational unities and tensions. In conclusion, I reconsider the participants' perennial quest for social acceptance and belonging, and not just in terms of their legal status, but also, connected to their fluctuating senses of being and becoming valued members of the nation.

\section{London, Urban Multiculture and Naming Racism(s)}

As part of the successful London 2012 Olympic bid, built on the imagined multiculturalism of London as "home" to "super-diverse" migrant communities as well as a tourist attraction to people from different parts of the world (Morpeth and Hylton, 2012), scenes of jubilation on the streets of central London were disrupted the following morning ( $7^{\text {th }}$ July 2005). That is, by the terrorist bombings of the London transport system. Following this travesty, Ken Livingstone (former London Mayor, and influential in the Labour-led anti-racist policies of the Greater London Council in the 1980s) ${ }^{1}$ made a statement about the confidence of cosmopolitan Londoners "to be themselves": to be a welcoming city for those in search of jobs, education, and a new "home” (cited by Massey, 2007: 8). Massey, in response, suggested:

Livingstone was surely right, in defiant response to the bombings, that people flock to London and will continue to do so because of the freedom it offers them 'to be themselves'. But people find their way here for other reasons too. They come because of

\footnotetext{
${ }^{1}$ Ken Livingstone is currently suspended from the Labour party, pending an investigation in to allegations of antisemitism.
} 
poverty and because their livelihoods have disappeared in the maelstrom of neoliberal globalisation...And it has to be at least a question as to whether London is a seat of some of the causes of those things (Massey, 2007: 8).

The current Mayor of London, Sadiq Khan, member of the Labour party, following the Brexit vote (2016) led the campaign \#LondonIsOpen. This campaign also constructed the popular image of London as welcoming, inclusive, and cosmopolitan. Khan's utopian vision of the city, like Livingstones' before him, problematically erases the impacts of urban, social, economic and cultural inequities (Georgiou, 2017; see also Back and Sinha, 2016). Khan and Shaheen (2017) in fact suggest that the life chances of successive generations of Black British men (in particular) has not risen, but has declined. Kamunge, Joseph-Salisbury and Johnson (2018: 2), further capture this stark social and racial inequity in their response to the burning of Grenfell Tower (in London):

While a $£ 10$ million 'regeneration' project sought to specifically clad over the visible inequity manifest in the tower's structure, we know it was that very cladding - erected to aesthetically please (or not to disturb) the occupants of nearby luxury flats - that saw those flames rise so quickly.

Magnified by the proximity of the urban rich and poor, the cruel dystopian realities of London are evident for all to see in the Royal Borough of Kensington and Chelsea, where the burnt shell of Grenfell Tower remains. Arguably, when burning a mock Grenfell Tower as part of a Guy Fawkes' celebration, by some "white" groups of people, can exist alongside the silent walking protest of racially marginalised communities - from London and elsewhere the quest for social justice remains an on-going political issue (Justice4Grenfell, 2018).

It is because of this political and socio-economic climate, and the longer histories of $\mathrm{g} /$ local forms of racial violence, that I am wary of reproducing sentiments of city-spaces, such as London, as evidence of what Sara Ahmed terms "happy multiculture" (2008). In 2015, a year after I completed the research for this article, I felt more fearful of accessing different city-spaces in and across my local neighbourhood than ever before. At the time, having 
given birth to my second (dual-heritage) child, my concerns related to our safety. I felt scared that our shared "brownness" visually marked us out as "not from here": non-natives who belong somewhere other than England (see McKittrick, 2015). Though, after joining a friendly mass of (different racial and ethnic) people walking the streets of London, protesting the continued austerity politics of a re-elected Tory government, on a night out in London with one "look", I felt out in my chosen space of leisure (Fanon, 1986). My gut instinct "told" me that my presence as a brown (Indian) woman physically disgusted the young, white, barman. He promptly refused to serve me and told me to leave the premises. My Dutch-Pakistani female friends (as sisters, who both can pass as white English people) and husband (of white English heritage) had no such problem, despite their elevated levels of inebriation. I took my relatively sober self out of this "public" house. The cosmopolitan "safety net" that I had subconsciously attached to my own image of London, in a single moment, metaphorically collapsed.

I am not sure why I felt taken aback by this incident, knowing that racial violence is common and can erupt (in similar and different ways) in and across different urban spaces, including those of London (Back and Sinha, 2016; Huq, 2012; Murji, 2017; Gilroy, 2004). This incident, nevertheless, as a second-generation daughter of British Gujarati Indian migrants to London, made me reflect on my own work, my own conceptual slippages, and those of other scholars who also perhaps un/intentionally under-state and/or gloss over the stark (and lived) realities of structural, cultural, and everyday racisms (see also Nayak, 2017). Terms such as cosmopolitanism, superdiversity, ethnicity, and multicultural conviviality, if not used carefully, can render invisible lived experiences of such racial discrimination and hurt. Many scholars have indeed explored urban multiculture as encompassing convivial encounters, alongside historical and contemporary manifestations of racism (e.g. Back and Sinha, 2016; Gilroy, 2004; Vincent, Neal and Iqbal, 2018). Yet, the "burning acts" (Nayak, 2017: 199) which materially and symbolically put racial bodies out "in" their spaces of "home", has made me more determined to explicitly name "race" and "racism" (see also Ali and Saini, 2018; Thangaraj et al, 2018; Valluvan, 2016). In relation to this racist, urban multicultural context - or what Back terms (1996) the metropolitan paradox - state and public celebrations of some South Asian communities in Britain (including those of Gujarati Indian heritage) as examples of model minority citizens, can operate simultaneously alongside re/presentations of "them" as culturally segregated, disloyal, and potentially terrorist members of the nation. 
In and between these two homogenising narratives, first and subsequent generations of British Gujarati Indians, must activate their citizenship and belonging, orientating complex, old and new, similar and different, racial hierarchies, which in these neo-nationalist political times, undermines rather than guarantees social acceptance and inclusion (Kapoor, 2018; Puar, 2007; Ratna, 2014; Valluvan, 2016). Thus, the conscious and subconscious negotiation of dynamic, multiple, interconnected, and historical forces of power - or what I have termed hierarchical assemblages of citizenship and belonging - are critically analysed in this article. By demonstrating the transnational and flexible agencies (Ong, 1999) of first generation, British Gujarati Indian husband and wife couples, I unpick how they as long-term citizens individually and together - access, read, and make claims to their spaces of "home", neighbourhood and nation.

\section{Everyday Life and Pedestrian Speech Acts}

De Certeau's (1984) work provides an instructive means to explore the pleasures, hopes, and realities of different racial and ethnic groups during these neoliberal, racist, post-racist times. The French philosopher's work is reflective of other poststructuralists, who similarly write about linguistics, power, and the construction of cultural meanings (e.g. Barthes, de Saussure and Foucault). De Certeau is particularly concerned with everyday life, and the (re)production of dominant discourses about the social world. He suggests that the ideological repertoires performed by political authorities, and public institutions, often include the selective use of "data" and/or "alternative facts" (Jones et al, 2017; Thangaraj et al, 2018). Although we may know such common-sense arguments are "a pile of crap" (de Certeau, 1984:188), the historical sticky-ness of colonial, imperial, European, white, sexual and gendered framings of the racial "Other", are nevertheless difficult to shift (Amos and Parmar, 1988). Thus, dominant discourses serve as "strategies" to re/produce rather than challenge, elitist, white supremacist, heteronormative, and patriarchal structures and cultures of power and control.

De Certeau though, does not reduce everyday actors to passive victims of forces outside of their own control. He argues that people consciously and sub-consciously read, and make sense of dominant discourses in/through their everyday habits and social practices. For instance, walking to the shops as a form of informal leisure can reveal much about how different communities see one another, no matter how fleeting the encounter between them (Wise, 2009). 
De Certeau uses the term "pedestrian speech acts" to refer to the process through which historical, colonial, imperial, geo-political, and ideological "facts" manifest, made meaningful through the concomitant processes of walking, reading, and accessing certain urban spaces rather than others (see also Back, 2017). De Certeau (1984), more specifically, argues that everyday practices make possible the (re)production of alternative 'tactics'; that is, different ways of accessing, being in, seeing, and speaking about the city. While individuals do not necessarily express everyday practices like walking as a form of resistance (Middleton, 2011), for de Certeau, "strategies" of control operate alongside alternative "tactics", shaping new, persisting, and shifting, (re)constructions of the city.

Thus, De Certeau is sensitive to how walking the city re/presents differentiated meanings, which he addresses further using the terms asyndeton and synecdoche. He suggests asyndeton represents a narrow view of city-spaces. In contrast, synecdoche illuminates the whole. Crang (2000: 137) further views the inter-relationship between asyndeton and synecdoche as a view of the city that both 'expands and contracts', oscillating between "big" and "small" constructions and re/presentations (see also Neal and Murji, 2015). Through a 'wandering of the semantic' (de Certeau, 1984:102), it is not my intention to focus upon asyndeton readings over and above synecdoche readings, or vice versa, because both matter in the creation and effects of pedestrian speech acts. The historical, complex, antagonistic, and nuanced, albeit unspectacular re/presentations of city-spaces, can thus be critically explored through the walking leisure pastimes of socially different groups of people, including those of British Gujarati Indian heritage. The materials generated from walking with each of the five Gujarati Indian couples (that is, participant observation notes, photos and mental maps) informed, respectively, walkers' individual interviews, serving as a tool to unpick their "big" and "small" re/presentations of London.

\section{Developing a gender-sensitive walking methodology}

Walking as a methodological tool has gained much traction including a proliferation of approaches, ranging from participant observations to interviews "on the move" (for example, Bates and Rhys-Taylor, 2017; Evans \& Jones, 2011; Fink, 2011; O'Neill \& Hubbard, 2010). Whilst space limitations prevent further discussion of these different approaches here, walking methodologies are valued as they enable researchers to capture a "feeling", at any moment in 
time, which is connected to being in and of a space (Parry and Johnson, 2007). Yet the privileging of white male (adult, middle-class, heterosexual, and able-bodied) re-readings of different spaces and places are often taken-for-granted (Morris, 2004; Springgay and Truman, 2017; Simonsen, 2004; Warren, 2017). Women walking the city, or further afield, in the wilderness, for example, can raise suspicion because they are seen to be out-of-place and at-risk (Jenks and Neves, 2000; Tew-Thompson, 2017). Thus, the arguments of feminist cultural geographers such as Massey (1994), McDowell (1999), and Rose (1993), are relevant to critically analysing the gendered construction of public spaces including those of leisure (Scraton and Watson, 1998; Watson and Ratna, 2011). Crucially, much further research is required to respond to the privileging of the "white" male (able-bodied, middle-class, and heterosexual) gaze, and to consider how different racial and ethnic minority men and women access, read and respond to different spaces and places, and what this may imply about their senses of belonging and citizenship (Rose, 1993; Warren, 2017).

Being cognisant of gender power struggles to access as well as re/present space - without regressing into colonial diatribes about the patriarchal and cultural sub-ordination of South Asian women - I took a number of steps: first, I chose to share my feminist anti-racist sensibilities with the research assistant (RA) so he understood the rationale underpinning my approach; and second, I requested each individual man and woman participant complete their own mental maps and photos (see below for further detail). As it transpired, all the men took photos on behalf of their wives (Author, 2017). Reacting to this emerging issue during the interviews, I invited the women participants to deconstruct their husbands" "framings" of different photos (and if relevant, the mental maps too). This strategy gave the women walkers the opportunity to analyse, and to expose what was potentially missing from such visual re/presentations. Despite my anticipatory efforts to ensure equity between the men and women walkers, I however, under-estimated the sociable potential of one-on-one semi-structured interviews (see Sinha and Back, 2014) which for these women, enabled them to have ownership over their own narratives about citizenship, belonging, and their everyday walking practices.

Building further upon debates about social difference, I recognise that disabled men and women who cannot walk, are always and already excluded through this methodological choice. The politics of how walking methodologies privilege the able-bodied construction of the built 
environment, and the challenges therein, requires much further sociological attention than what I can do justice to here (for further debate, see Morris, 2004; Vujakovic and Matthew, 1994). Thus, I acknowledge that this study focuses upon the research participants' able-bodied lives, and their taken-for-granted informal walking practices: that is, not necessarily as a form of serious leisure and/or connected to an official walking club, but as part of their everyday routines to walk around the local neighbourhood (on their own and/or with different family/ friends); as husband and wife couples to complete errands and/or to go to the shops; and to meet-up as a group of five couples to walk, sit together, and exchange stories relevant to their trans-local senses of being and belonging (see Ratna, 2017 for further debate). After considering the merits and limitations of different research methods (Evans and Jones, 2011; O'Neill and Hubbard, 2010), I chose to adopt a combination of mental maps, photo-elicitation, participant observations, and semi-structured interviews, to capture the participants' everyday walking practice in and around the spaces of their local neighbourhood and residential "homes".

\section{The research process, and researching with/on family and friends}

Prior to commencing the research, the RA went through an information sheet with each couple, so that they understood the nature of the study, and what was required of them. The research itself constituted three phases: first, the RA walked with five husband-wife couples, respectively, on a route of their choice. In total, the RA walked twice with each couple (usually once in the morning and once during the evening), over a period of two-weeks, during the month of June 2014. After each walk, the RA wrote-up his observational notes in a research diary, commenting on relevant conversations, encounters and incidents, that he had witnessed and/or heard about the spaces and places they walked through and across. Second, the RA requested the participants to draw a mental map illustrating one of their usual walking routes (in any way that made sense to them). Additionally, they were asked to take photos with a disposable camera (provided by the RA) of any places they frequently walked past and/or deemed as meaningful to them. Third, the RA and I annotated and talked through the participant observation notes, maps and photos, which I then used to inform the semi-structured interview questions. For example, this included looking at a range of photos with the research participants, enquiring about their rationales for walking, the places where they went to and/or avoided, and also about their wider experiences of migration, settlement, and belonging. All the interviews were completed by the end of July 2014. 
The RA for this project was my father (Ramji), and both my mother (Kesar) and father were included in the research as participants. The other four husband-wife couples (Amrat and Hirji; Jasu and Manji; Kanta and Premji; and Radha and Lux $)^{2}$ were known to me as friends of my parents', whom they often walked with on their daily travels. Whilst other scholars may question the impartiality of my research approach, in defiance, I take solace in research that values co-researching with friends which for me, includes members of my family (e.g. Chowdhury and Philipose, 2016). Engaging in alternative ways of knowing beyond the European canon, and taken-for-granted remnants of positivistic ethical traditions, has been a liberating experience for me: that is, as an act of resistance to challenging the Master's rules (Lorde, 1997). I, therefore, refuse to apologise for using my social and cultural capital, outside of the elite, patriarchal and white supremacist structures of academia, to research the lives of my parents, and our family friends. They collectively inspired me to write the stories of mara manso (my people) knowing that we cannot step outside the discursive power of language that constitutes our very material beings as not white; meaning, racially Other.

Holding a critical lens to my familial and friendship networks was, however, a difficult task. But I did so to trouble idealised images of family life, love, and affinity, making visible power struggles, differences, and unforeseeable tensions. For example, I suggest it is naïve to think family members and friends (who are often viewed as holding pre-existing relations of trust and rapport) are more likely to share knowledge about their lives, just because they are family members and friends (see also Puwar, 1997). Inspired further by Christou (2011) and ToliaKelly (2009), I tried to anticipate issues related to working with, for and about members of my family. One such issue included negotiating the problem of in/authentic interview translations, from the Gujarati Indian language to English. In this respect, I found Falcon's (2017) advice to be useful. She warns that language is a site of struggle, and translations from peripheral

\footnotetext{
${ }^{2}$ Even although as part of the process of confirming ethical consent, the participants were asked to pick pseudonyms, they all chose not to. In the words of Radha, she stated that being anonymous did not necessarily protect her from being targeted by racist and fascist groups. I also agree with Webster (2018) who questions positivistic research traditions of using anonymity as a default position. Sinha and Back (2014) further add that being named can be empowering for participants, to claim their life-stories.
} 
languages to English involves colonial, racial, and gendered regimes of power and control (see also hooks, 2000). The RA and I, as fluent speakers of both Gujarati and English, therefore took extra care to transcribe the participants' words to use, rather than abuse, intended meanings (Kim, 2013). As the gendered construction of the Gujarati Indian language also implicitly denotes "respect" from younger to older people, my use of this vernacular possibly eased any tensions that may have arisen during the interviews between me as a younger woman (in her late-30s) wanting to gain knowledge from the older participants (who were all in their 60s at the time of the research). I also reviewed field-notes with Ramji, listening to him, speaking about his observations, and together, unpicking emerging gendered, racialised, ethnic, religious, generational, class and caste problems and possibilities, reflexively re-reading themes to unpick any nuances, tensions, and complexities. Through this process, we began to analyse and synthesise different elements of the fieldwork, co-constructing meanings in and through our evolving father-daughter and researcher relationship. I then individually read across the fieldwork findings, and thematic codings of participant interview transcripts, to develop the arguments for this article: this specifically related to exemplifying lived experiences of multicultural conviviality, different racial positionings and posturings, and thinking through the implications of other connected social ties, unities, and tensions.

\section{Multicultural Conviviality}

Like many Gujarati Indian citizens, many of the participants arrived in England via East Africa. This process involved negotiating complex and discriminatory state-based immigration policies, in and through the 1960s and 1970s. In addition, they often faced everyday racist hostilities from mostly "white" English, racial majority neighbours. In his interview, Hirji, who initially lived and worked in the North-West of England, spoke of the racism that he had experienced which, in part, prompted his move to North-West London in the late 1960s. He talks positively about his early experiences of living in London suggesting many African Caribbean people in the area, at the time, offered support with getting jobs. He also suggests, through his daily walks around the small block that makes up his immediate neighbourhood (see Figures 1 and 2) in the last decade he has seen much change in terms of the racial and ethnic diversity of the place. When I ask Hirji how he sees this change, he offers a picture of a friendly neighbourhood: 
Yes, it doesn't make any difference, it [racial and ethnic diversity] is changing slowly day-by-day. You say hello [when walking past neighbours] ...you don't see the difference, people do say hello to you, so you don't feel like they are racist.

He sees the changing construction of his "home" and neighbourhood, and friendly encounters with his neighbours, as further evidence of the positives of living in a multicultural space without having to endure the daily impacts of racism.

\author{
$<<$ Insert Figure 1 here $>>$ \\ $<<$ Insert Figure 2 here >>
}

Jasu, too, in her reflections about walking to and from her allotment, a patchwork of gardening plots located behind her house, speaks about the reason for making this daily trip. She tells me that after the unexpected death of her son, her other son leased an allotment site to help her deal with this tragedy. In relation to this, I asked her 'do you talk to them (other gardeners) when you are at the allotment?' She responded:

'Hello, how are you?' Sometimes we sit down and have a general talk...I am the only Indian. All mixed people are there. Some Italians, some Bulgarians, some Kosovans, Europeans, Irish and West Indians... One or two are original "white" [English], others are all outsiders. Lots of Irish too.

Aarti: So, most of you are "outsiders"?

Jasu: Yes, all friendly people

Jasu represents this space as friendly, bonding individuals who not only share an interest in growing fruit and vegetables, but also, to one another (Neal et al, 2018). Jasu, interestingly, also includes some "white" European groups - long-term Irish communities - in her depiction of racial outsiders who, arguably, in other contexts, may hold honorary positions of whiteness in relation to those positioned as "original" whites (Ratna, 2014). 
Despite many public and policy discourses about South Asians (as a whole) being self-segregating, this expression of community "from below" (Gilroy, 2004) reflects how people can and do live together across difference, and how this may manifest through public spaces of leisure such as gardening.

Ramji, in his interview, talks about walking across city-spaces and places where, over time, the socio-demographics of the local population has continued to change. For instance, some mornings he walks past a local newsagent, a series of council flats, a local primary school, and along the perimeter of a park. In relation to this local neighbourhood, Ramji states 'to be "white" English, is to be a minority presence'. He sees the changing racial and ethnic dynamics as not reflective of a migrant "take over" - as popularised through historical and contemporary state rhetoric - but as conducive to the creation of a "mullato" race. Ramji views the term "race" as becoming meaningless, as inter-racial relationships become more common in and across the area where he lives. Ramji's optimistic prophesy, whilst positioning his own ontological comfort as a long-term Gujarati Indian settler, living amongst a collective of racial and ethnic communities, unfortunately erases the on-going impacts of racism, and other social and economic urban inequities.

\section{Racial Positionings and Posturing}

By deconstructing the pedestrian speech acts of the Gujarati Indian walkers, it became apparent that friendly relations existed alongside racial tensions and hostilities. For instance, Jasu, despite the positive sense of community previously expressed by her at her allotment, goes on to suggest that Eastern European migrants who now live along her street possess a different mentality, implying they do not care about the spaces and places of the local neighbourhood. According to Ramji's research diary notes, Jasu sees the presence of Eastern Europeans as a symbol of 'not how it used to be, when you could leave milk-money in a bottle outside of your doorstep'. In her interview, I asked Jasu about the scapegoating of upna manso (our people) when they first arrived in the U.K., to make visible the links between her accusatory claims against Eastern European people (as "thieves") and the different stereotypes directed at first 
generation African Caribbeans (e.g. as "criminals") and South Asian people (as "self-segregating"). She expands upon her claim by re-imagining the "ideal" Gujarati Indian model minority citizen:

There were lots of jobs, our [Gujarati Indian] people were working very hard at that time. They came penniless so they knew they had to work hard to survive in this country. We need to work, work and work. Now people's mentality is completely different...If people [meaning Eastern Europeans] don't work, what are they going to eat? If they don't work, how are they going to survive?

Jasu endorses a neoliberal narrative of individual work ethic and success, erasing the significance of local welfare provision - and the emergence of various anti-racist policies and schemes introduced by Livingstone who lead the Greater London Council in the 1980s (Massey, 2005) - that supported families like her own, however inadequate and discriminatory those services might have been (then and now). Nevertheless, Jasu reproduces a divisive discourse about "us" as deserving citizens, and "them" as undeserving migrants (see Jones et al, 2017).

Amrat's testimony continues with the theme of Eastern European migrants (lumped together, whoever they may be) as "welfare scroungers". In her daily walks, across the residential streets of her local neighbourhood to her sister's house, a few streets across from and parallel to her own street, she comments on the rise of Eastern European neighbours. When questioned on her opinion, unlike her husband Hirji, she reproduces a far-right conservative diatribe about "family-values" (meaning in terms of a heteronormative family) positioning Eastern Europeans as 'wrong' for the country. She further states:

...if they come and work, get the job, that's not bad. But if they [Eastern Europeans] do nothing, especially the young, get lazy, stay only for benefits and to have families, then that is wrong. We got settled before having a family, a baby. We were thinking of the future when we came to this country. Okay, might be ladies are not working, looking 
after babies, that's fine but men should work. That I object. People living on benefits, not working.

This racial positioning is selective; Amrat is unable to have children but recalls images of hardworking mothers and fathers as part of her own gendered story of citizenship. Some of the participants recognised such discourses as stigmatising but nevertheless, spoke about them in their own re/presentations of local spaces. For example, Kesar, in her interview, mentions coaches of Eastern European migrants that (supposedly) arrive every week, parking on the main high street that she walks along most days to go to the Indian grocers (see Figure 3). Over time, this spot, as mundane as it is, has become associated to wider narratives about unwanted Eastern European migrants. Indeed, upon seeing the photo of the same park from a different angle (see Figure 4) - at the outdoor gym area that he walks to but confesses not to use - in his interview, I query Ramji about the presence of Eastern European migrants in this area. Ramji responds that he has heard stories about Eastern European men living in the bushes, defecating in public. He then goes on to dismiss these stories as something he has not personally witnessed. Therefore, these narratives, not substantiated with any actual evidence, links a small and unspectacular space to mythical images of "coaches stuffed" (Kesar's words) with apparently uncivilised Eastern European people. Such big readings of small spaces fuel, rather than challenge, discriminatory and homogenising views of different Eastern European communities.

$<<$ Insert Figure 3 here >>

$<<$ Insert Figure 4 here $>>$

\section{Contesting citizenship: Social unities and tensions}

In their respective interviews, Radha, Lux and Premji, enunciate their own differing views about seeing and walking past an increasing number of Eastern European people, neighbours, and shops. For example: 
Lux: Government [Labour and Tory] did not expect that flux, they suggest a million people [Eastern European] have come here [England] to settle. There are always shortages of housing and you can see rental prices have gone-up, and people [Eastern European] do not really get high-paying jobs, because most of them are in what you call the labour industry. They are surviving but they have a mind to go back. Those who are working are surviving. Those who are very young, have the benefit of their health, start their family and have children, get child benefit, get money in, so they get housing, and they don't have to pay the rent. Some are living off benefits but most of them are working in the building industry.

Premji: When we [Indians] came it was better, you could get a job quickly. There was a demand for people, especially if you were in the building trade... Now there is a problem because of Eastern Europeans, you can't get jobs easily...If they [the government] tell Eastern Europeans to go back, same can apply to us [Gujarati Indians]. We would have to go back...nobody wants to go back.

Radha: Yes, we [Gujarati Indians] have the right, they ["white" English people] might say otherwise, that's what they say but not the [British] government. They have given us the right to stay here (emphasis added).

Together, the testimonies reveal the fragility of the walkers' senses of belonging. As specifically noted by Premji, the British government could send them back to their diasporic "origins" at any time. For him, this would be to an ancestral space of "home" that he has never known, having grown up and lived in Kenya ${ }^{3}$ - rather than India - prior to getting married and moving to England with Kanta. Thus, like other South Asian groups, he too could be deported by the British state, at any time, irrespective of legal status (Kapoor, 2018).

$<<$ Insert Figure 5 here $>>$

\footnotetext{
${ }^{3}$ After the forced expulsion of South Asians from Kenya in the late 1970s, this also may be a "home" that he no longer recognises from his childhood and/or has any desire to return.
} 
Despite the community solidarity which existed in and between many racial and ethnic groups, as first-generation citizens who shared a politics of resistance to racism (e.g. see Hirji's testimony above), it is naïve to assume absolute racial and ethnic solidarity existed then or now. Arguably tensions did, and still do exist, in terms of histories of caste, class, gender, religion, age, and generational differences. For example, in relation to intra-religious relations, I queried Ramji's research diary notes which suggested a new Hindu temple had been built in the local area (see Figure 5) and because he walks past it most days, I questioned whether he had been inside to see it. He responded that he did not like going into this temple to pray, as Hindus from a different caste and religious sect would "look" at him. This was not "the look of love" but a challenging "look, what's he doing here?" (See Fanon, 1952). Kesar and Ramji, in talking about another research diary note with me in their respective interviews (see below), also hinted at intra-ethnic antagonisms when they recounted the stabbing of a Sri Lankan boy, at a park that they walk past on a regular basis (see Figures 3 and 4). Despite images of tranquillity, this very ordinary space is not only deemed unclean (through narratives about homeless Eastern European men living in the bushes) but, also, unsafe (through the presence of ethnic gangs). The diary entry reads:

As the park is a bit isolated, and not many people are walking at night-time, it does not feel safe and one time, a body of a Sri Lankan boy was found. We found out via the local press that it was a problem internal to the (Sri Lankan) community (Research Diary, June $11^{\text {th }} 2014$ ).

Despite the religious and ethnic divisions noted in relation to their use and access of various public spaces, this did not necessarily deter them from living in the local area. Kesar, regardless of her middle-class sensibilities (Ratna, 2017), stated in her interview that she did not intend to move anywhere else. Ramji, though, in conversation with me about this diary entry, suggested that many other Gujarati Indians now live in highly sought-after places, in and across different parts of the city. He refers to this as a type of "brown flight". He further claims in his interview testimony: 
[White English people] migrated to the countryside or to outside of London as they could probably afford bigger houses. And that is also what is happening to some Indians, they are going [to other places]....as they can afford bigger houses there.

Aarti: So, they are going to areas which are less multi-cultural?

Ramji: More multi-cultural, but less poor communities.

Premji's map (Figure 6) and some photos (see Figures 7 and 8) illustrates this middle-class "brown flight" to more affluent areas where his daughter now lives, and another locality where his son owns a dentist clinic. Away from the hub of his residential area (see Figure 7), Premji's walking preferences also show high streets that are not as busy as his own and, are therefore, perhaps seen as more aesthetically pleasing to his children.

\author{
$<<$ Insert Figure 6 here $>>$ \\ $<<$ Insert Figure 7 here $>>$ \\ $<<$ Insert Figure 8 here $>>$
}

When examining some of the photos taken by the walkers of their local neighbourhood, I - as a middle-class professional who moved out of this area more than a decade ago - could not help but think: "this place seems okay" (albeit knowing that these are static re/presentations). As I looked again at the photos, I noticed the litter (see Figure 2); I pondered how a seemingly pleasant park could be associated to acts of murder and homelessness (see Figures 3 and 4); and that the images of convenience stores - one after the other - must be there as they respond to the consumer needs of the local population (see Figure 9 and 10). The way such small spaces are lived by the walkers consciously and sub-consciously constructs meanings, about who belongs, where and why. These perceptions whilst based upon a mix of historical, contemporary, socio-economic, political realities and falsities, frames how dynamic hierarchical assemblages of citizenship and belonging are negotiated, re/produced, and contested. 
$<<$ Insert Figure 10 here >>

\section{Conclusion}

Across the Gujarati Indian walkers' differing pedestrian speech acts, they read "small" details of the city by reinforcing and reproducing "bigger" spatial boundaries, and discourses about who belongs, who does not, and who can never belong. While a resistant politics is enacted in/through the daily lives of the walkers, using their agencies to mobilise their own senses of national, racial and ethnic belonging, it does very little to alter structures of inequality and/or hierarchical assemblages of citizenship and belonging. It is a sad tale of populist and exclusionary politics promoting self-serving quests for cultural recognition, masking wider economic inequities, and hierarchical assemblages of racial, ethnic, religious, caste, class, gender, and generational unities and tensions. It would be problematic, however, to assume that the Gujarati Indian walkers included in this research are un/intentionally "just" the racial aggressors (towards Eastern European people) rather than also victims of racism. They are both but not in isolation. By this I suggest that between the material and discursive re/presentations of many British Gujarati Indians, as both model minority and disloyal citizens, their belongings (and those of their British-born children) remain tenuous, despite their legal and long-term status as citizens of the nation. Thus, the racisms that the British Gujarati Indian walkers evoke, about Eastern European migrant communities, for instance, are not new in that they signify something new/ distinct from past racisms. But, that they are indicative of older authoritarian regimes of power, and the British (neo-)colonial politics of divide and rule. The Gujarati Indian walkers' stigmatisation of Eastern European people (to varying extents), indeed serves as a performative device to stake their own claims to the nation. Concomitantly, the hopes, needs, and belongings of different Eastern European communities, remains absent in this article. Arguably, their hypervisibility yet invisibility becomes another mechanism through which "they" are homogenised, and racially "Othered" without recourse to refute claims made about "them".

At the time of writing this article, the public outrage against the deportation of the Windrush generation demonstrates the precariousness of citizenship, and the state's role in disenfranchising legal, and long-term residents of the nation. Such racialized jockeying from within differentiated, complex, and changing hierarchies of citizenship and belonging, can only serve to perpetuate a politics of division rather than a politics of solidarity. I add my voice to those of 
many others, recognising it is time for a different type of politics: that is, one that re-centres race and racism, and undoes the historical legacies of discriminatory immigration laws, policies and practices. To escape the vicious cycle of differential racial and ethnic scapegoating, our political actions must build "on the edge of each other's battles" (Sivanandan, 2008; The Santa Cruz Feminist of Color Collective, 2013) fostering allegiances that recognise our interconnected citizenship rights as new, old, similar and different, racialised communities of people. Spaces of leisure whilst not necessarily politically "neutral", are spaces where acts of resistance, solidarity and friendship, have the potential to foster alliances across new and shifting hierarchical assemblages of citizenship and belonging (e.g. see Amin, 2012; Chowdhary and Philipose, 2018; Jackson, 2018; Thangaraj et al, 2018), uniting us even as socio-economic, cultural and political forces divide us, from one another, and the spaces and places that we choose to call "home".

Acknowledgements: I would like to thank Dan Burdsey, Mark Doidge, Viji Kuppan, and Chris Webster, for feedback on previous drafts of this article as well as the feedback and support of the Editor-in-Chief Vanessa May, the Publications Assistant Sophie Jacques, and the four anonymous reviewers.

I dedicate this paper to my much loved friend, Rajesh K., (1975-2003).

\section{References}

Ahmed, S (2008) Multiculturalism and the Promise of Happiness, New Formations: A journal of culture, theory, politics, 63: 121-137.

Amin, A (2012) Land of Strangers, Cambridge; Malden: Polity Press.

Amos, V and Parmar, P (1984) Challenging Imperial Feminism, Feminist Review, 17(1): 3-19.

Back, L (2017) Marchers and Steppers: Memory, City Life and Walking in C. Bates \& A. Rhys-Taylor (Eds.) Walking Through Social Research, New York; London: Routledge: 20-37. 
Back, L, Sinha, S, Bryan, C, Baraku, V, and Yembi, M (2018) Migrant City, Oxford; New York: Routledge.

Back, L, and Sinha, S (2016) Multicultural Conviviality in the Midst of Racisms Ruin, Journal of Intercultural Studies, 37(5): 517-532.

Back, L. Sinha, S., and Bryan, S. (2012) New Hierarchies of Belonging, European Journal of Cultural Studies, 15(2): 139-154.

Bates, C and Rhys-Taylor, A (Eds.) (2017) Walking Through Social Research, New York; London: Routledge.

Bhambra, G (2018) Turning Citizens into Migrants accessed at https://www.redpepper.org.uk/talking-about-migrants-is-a-dogwhistle-way-of-talking-about-race/ on $18^{\text {th }}$ April.

Chowdhury, EH, and Philipose, L (2016) (Eds.) Dissident Friendships: Feminism, Imperialism, and Transnational Solidarity, Urbana, Chicago and Springfield: University of Illinois Press.

Christou, A (2011) Narrating lives in (e)motion: Embodiment, belongingness, and displacement in diasporic spaces of home and return, Emotion, Space and Society, 4(4): 249257.

Crang, M (2000) Relics, places and unwritten geographies in the work of Michael de Certeau (1925-86) in M. Crang (Ed) Thinking Space, London; Routledge: 136-153.

De Certeau, M (1984) The Practice of Everyday Life, Berkeley: The University of California Press. 
Evans, J, and Jones, P (2011) The walking interview: Methodology, mobility and place. Applied Geography, 31: 849-858.

Falcon, SM (2016) Transnational Feminism as a Paradigm for Decolonizing the Practice of Research, Frontiers, 37(1): 174-194

Fanon, F (1952) Black Skin, White Masks, London: Pluto Press.

Fink, J (2011) Walking the neighbourhood, seeing the small details of community life: Reflections from a photography tour, Critical Social Policy, 32(1): 31-50.

Georgiou, M (2017) Is London Open? Mediating and ordering cosmopolitanism in crisis, International Communication Gazette, 79(6-7): 636-655.

Gilroy, P (2004) After Empire: Melancholia or Convivial Culture? London: Routledge.

Grenfell4Justice (2018) 'Welcome to justice for Grenfell', available at https://justice4grenfell.org/ on December $9^{\text {th }}, 2018$.

Huq, R. (2012) Darkness of the Edge of Town: Depictions of Suburban 'Asian London', in Popular Youth Culture, Wasafiri, 27(4): 3-14.

Jackson, E (2018) Valuing the Bowling Alley: Contestations over the preservation of spaces of everyday urban multiculture in London, Sociological Review, https://doi.org/10.1177/0038026118772784

Jenks, C, and Neves, T (2000) A walk on the wild side: Urban ethnography meets the Flâneur, Cultural Values, 4(1): 1-17.

Jones, H, Gunaratnam, Y, Bhattacharyya, G, Davies, W. Dhaliwal, S, Forkert, K, Jackson, E. and Saltus, R (2017) Go Home? The Politics of Immigration Controversies, Manchester: Manchester University Press. 
Kamunge, B. Joseph-Salisbury, R, and Johnson, A (2018) Changing our fate in the fire now, in A. Johnson, R. Joseph-Salisbury and B. Kamunge (Eds) The Fire Now: Anti-Racist Scholarship in Times of Explicit Racial Violence, London: Zed Books.

Kapoor, N (2018) Deport, Deprive and Extradite: $21^{\text {st }}$ State Extremism, Verso Books.

Khan, O, and Shaheen, F (Eds) (2017) Minority Report: Race and Class in post-Brexit Britain, London: Runnymeade.

Massey, D (2007) World City, Cambridge; Malden: Polity Press.

Massey, D (1994) Space, Place and Gender, Cambridge; Malden: Polity Press.

McDowell, L (1999) Gender, Identity and Place, Cambridge; Oxford: Polity Press.

Meghji, A, and Saini, R (2017) Rationalising Racial Equality: Ideology, Hegemony and PostRacialism among Black and South Asian Middle-Classes, Sociology, DOI: $10.1177 / 0038038517726645$

Middleton, J (2011) Walking in the City: The Geographies of Everyday Pedestrian Practices, Geography Compass, 5(2): 90-105.

Morpeth, D, and Hylton, K (2012) 'Race' Matters and the East End', International Journal of Sport Policy and Politics, 4(3): 379-396.

Morris, B (2004) What we talk about when we talk about "walking in the city", Cultural Studies, 18(5): 675-697.

Neal, S. Bennett, K. Cochrane, A, and Mohan, G (2018) Community and Conviviality: Informal Social Life in Multicultural Places, Sociology, DOI: 10.1177/0038038518763518

Neal, S and Murji, K (2015) Sociologies of Everyday Life: Editors' Introduction to the Special Issue, Sociology, 49(5): 811-819. 
O'Neil. M, and Hubbard, P (2010) Walking, sensing, belonging: ethno-mimesis as performative praxis, Visual Studies, 25(1): 46-58.

Ong, A (1999) Flexible Citizenship: The Cultural Logics of Transnationality, Durham, London: Duke University Press.

Parry, D, and Johnson, C (2007) Conextualising leisure research to encompass complexity in lived leisure experiences: The need for creative analytical practice, Leisure Sciences, 29: $119-130$

Puwar, N (1997) Reflections on Interviewing Women MPs, Sociological Research Online, DOI: http://www.socresonline.org.uk/2/1/4.html

Ratna, A (2014|) 'Who are ya?' The national identities and belongings of British Asian football fans, Patterns of Prejudice, 48:3, 286-308.

Ratna, A (2017) Walking for leisure: the translocal lives of first generation Gujarati Indian men and women, Leisure Studies, 36:5, 618-632.

Rose, G (2003) Feminism and Geography: The Limits of Geographical Knowledge, Cambridge; Maiden: Polity Press.

Scraton, S, and Watson, B (1998) Gendered Cities: Women and Public Leisure Space in the Postmodern 'city', Leisure Studies, 17(2): 123-137.

Sinha, S, and Back, L (2014) Making Methods Sociable: Dialogue, Ethics and Authorship in Qualitative Research, Qualitative Research, 14(4): 473-487.

Sivanandan, A (2008) Catching History on the Wing: Race, Culture and Globalisation, London: Pluto Press. 
Springgay, S, and Truman, S.E (2017) A Transnational Approach to Walking Methodologies: Embodiment, Affect, and a Sonic Art Performance', Body and Society. DOI:10.1177/1357034X17732626

Thangaraj, S, Ratna, A, Burdsey, D and Rand E (2018) Leisure and the racing of national populism, Leisure Studies, 37:6, 648-661

The Santa Cruz Feminist of Color Collective (2014) Building on "the edge of each other's battles": A feminist of color multidimensional lens, Hypatia, 29(1): 23-40.

Tolia- Kelly, DP (2009) The geographies of cultural geography 1: identities, bodies and race. Progress in Human Geography, 1-10. doi: 10.1177/0309132509343378

Watson, B and Ratna, A (2011) Bollywood in the park: Thinking intersectionally about public leisure spaces, Leisure/ Loisir, 35(1): 71-86.

Warren, S (2017) Pluralising the walking interview: researching (im)mobilities with Muslim women, Social and Cultural Geography, 18(6): 786-807.

Wise, A (2009) Everyday Multiculturalism: Transversal crossings and working-class cosmopolitans, in A. Wise and S. Velayutham (Eds.) Everyday Multiculturalisms, London: Palgrave Macmillan: 21-45.

Yuval-Davis, N, Wemyss, G, and Cassidy K (2018) Everyday Bordering, Belonging and the Re-Orientation of British Immigration Legislation, Sociology, 52(2): 228-244.

Biography: Aarti teaches sociology at Solent University. Her research focuses upon debates about race, gender, migration, diaspora and national belonging. 


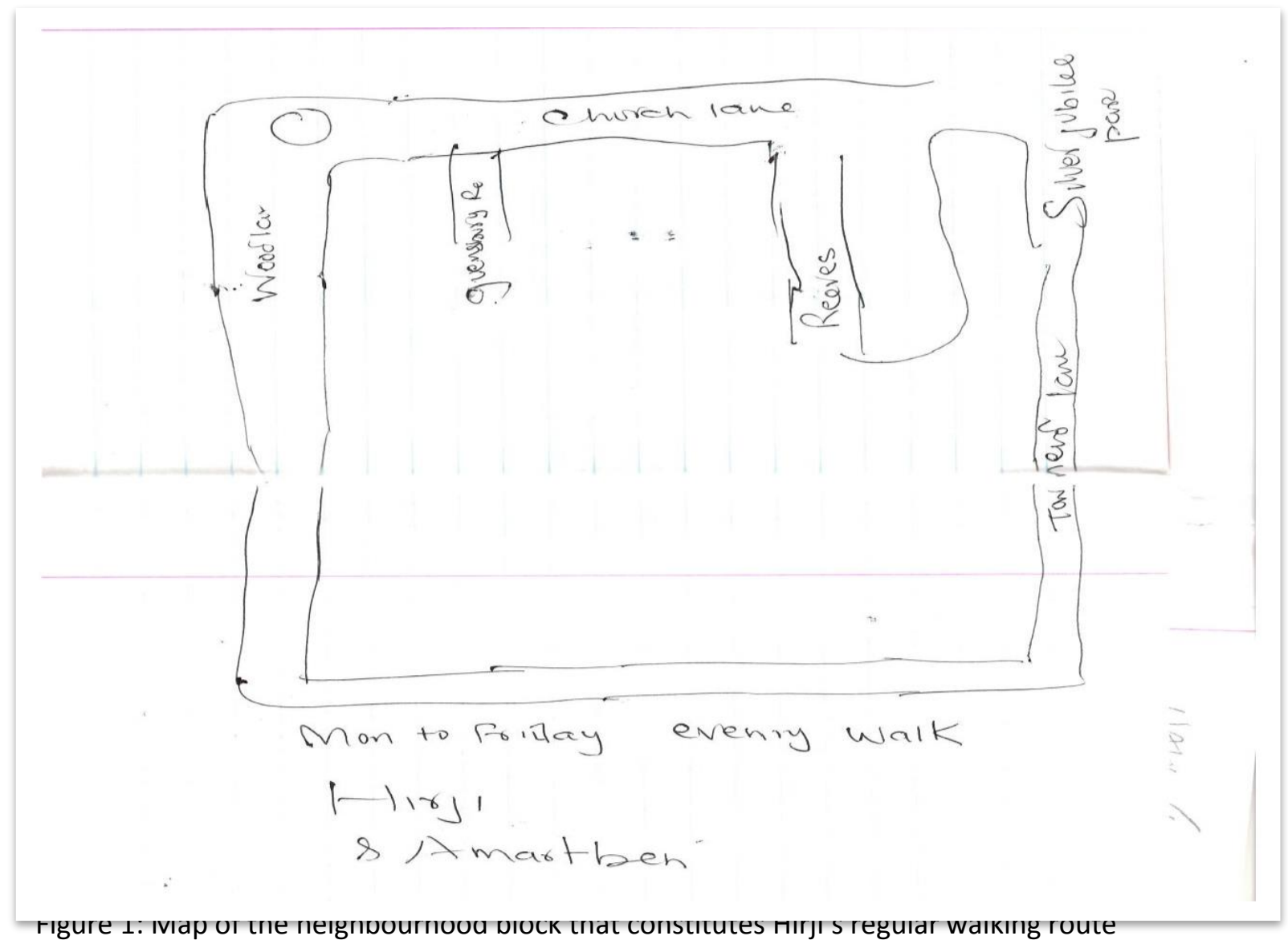

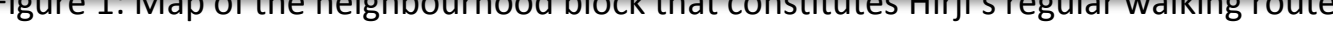

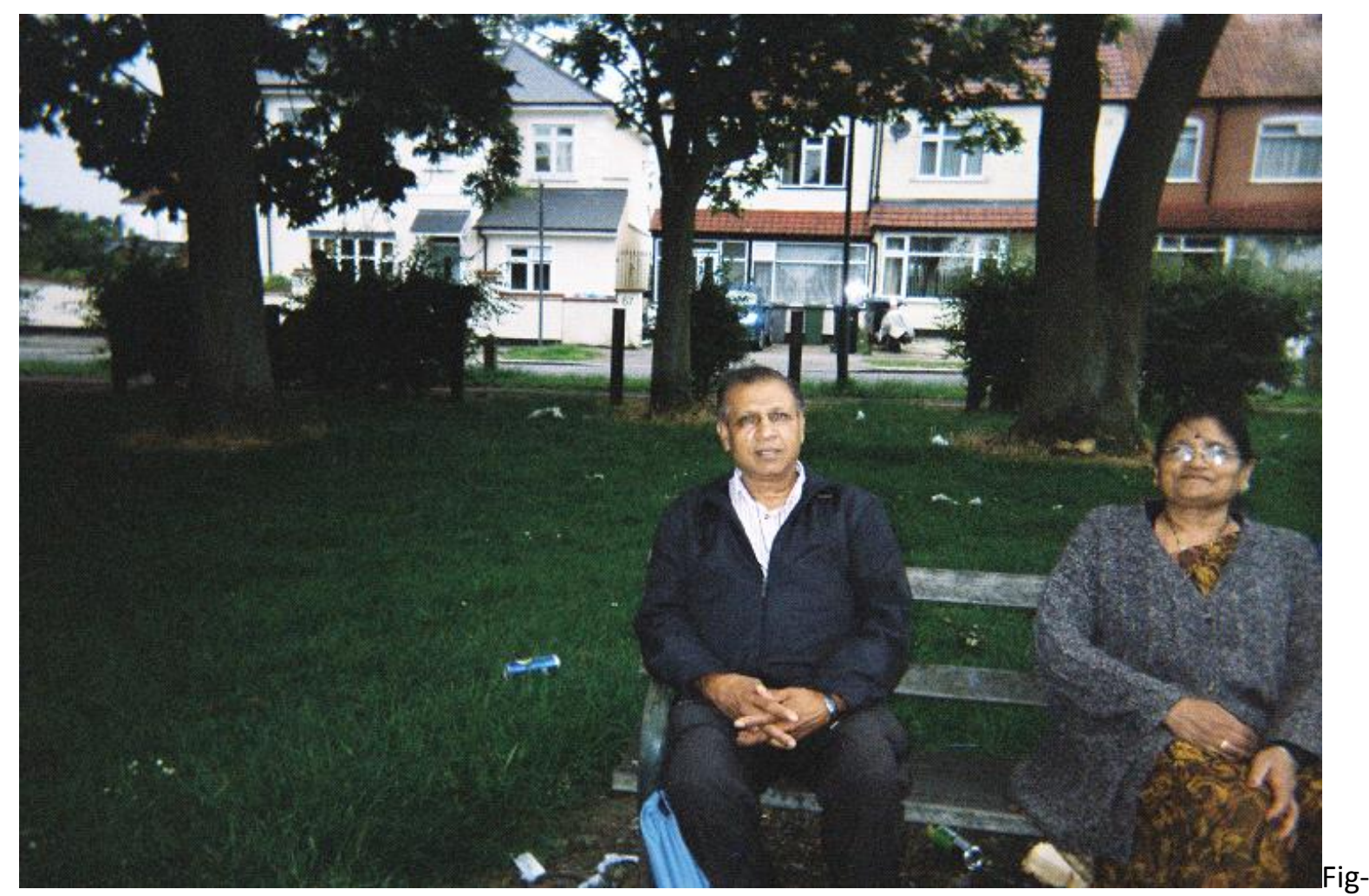

ure 2: Hirji sat with his wife, Amrat, at a park bench not far from the end of the road where they live (see Figure 1). 


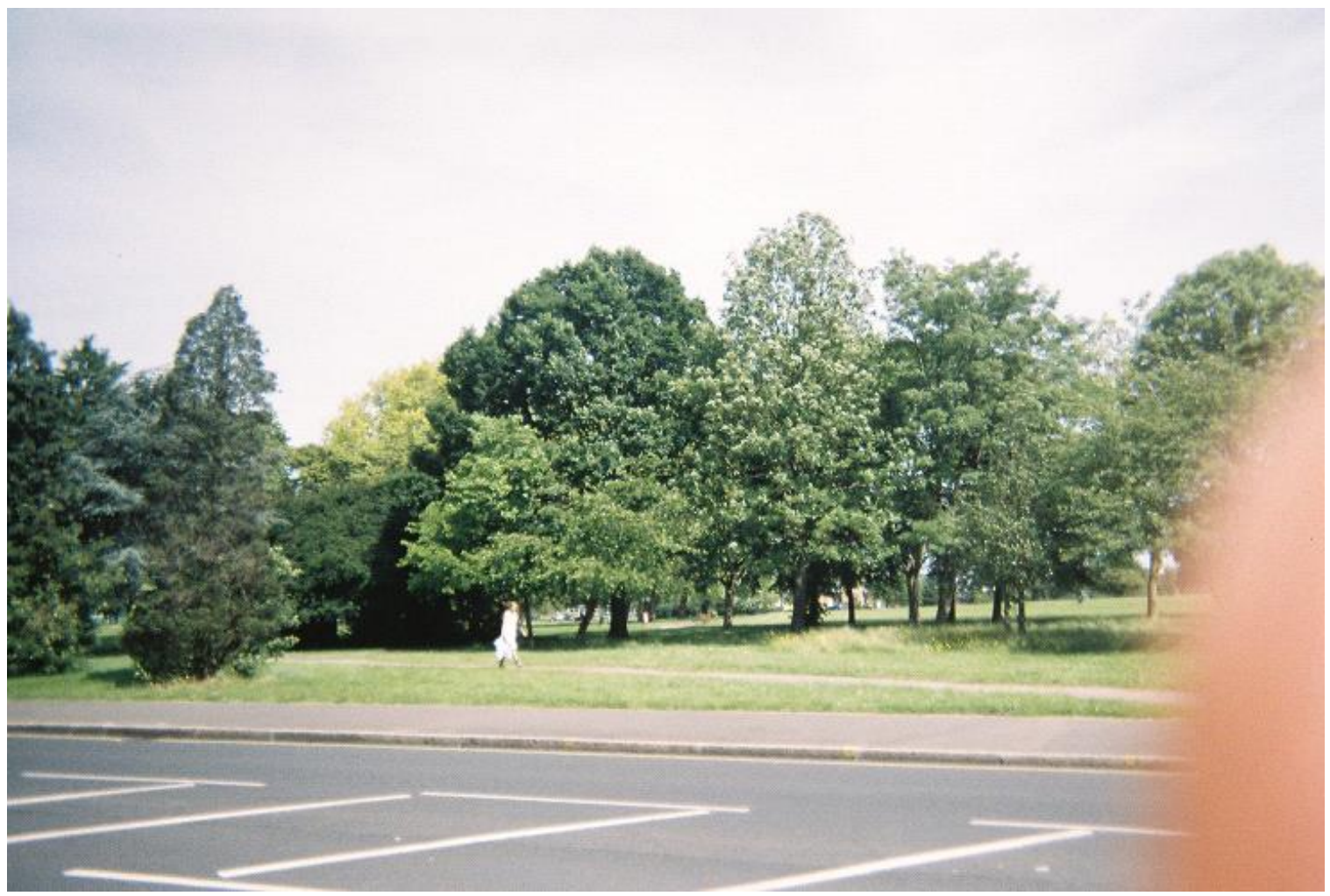

Figure 3: A photo taken by Ramji of a spot across the road, where "coach-loads" of European migrants are supposed to "descend" every week.

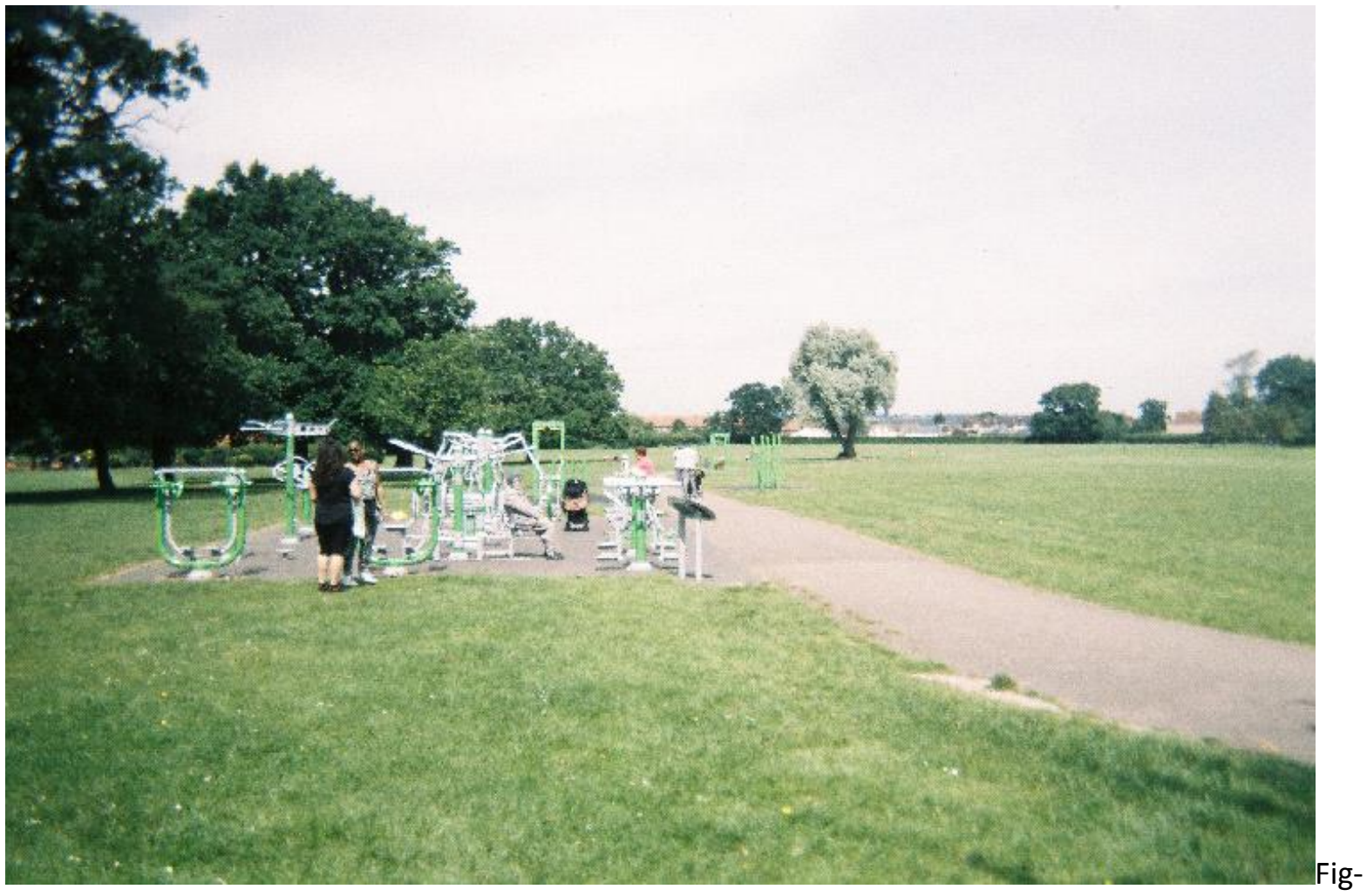

ure 4: Ramji's photo of an outdoor gym area located at a local park where the bushes, at the far lefthand side of the photo, is allegedly to be where homeless Eastern European men live. 


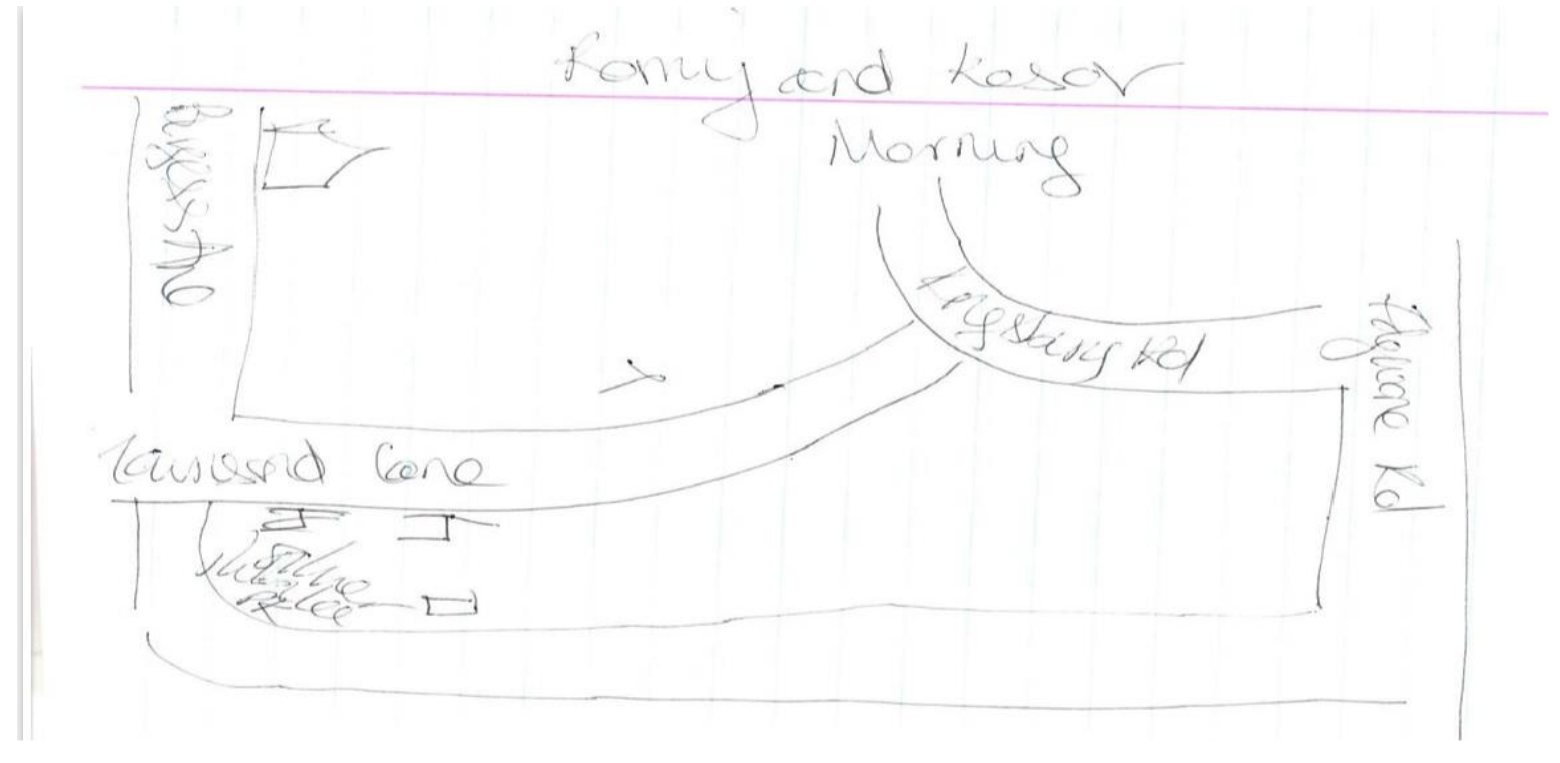

Figure 5: A map drawn by Ramji which locates the position of a Hindu temple, marked by a " $\mathrm{T}$ "shaped squiggle.

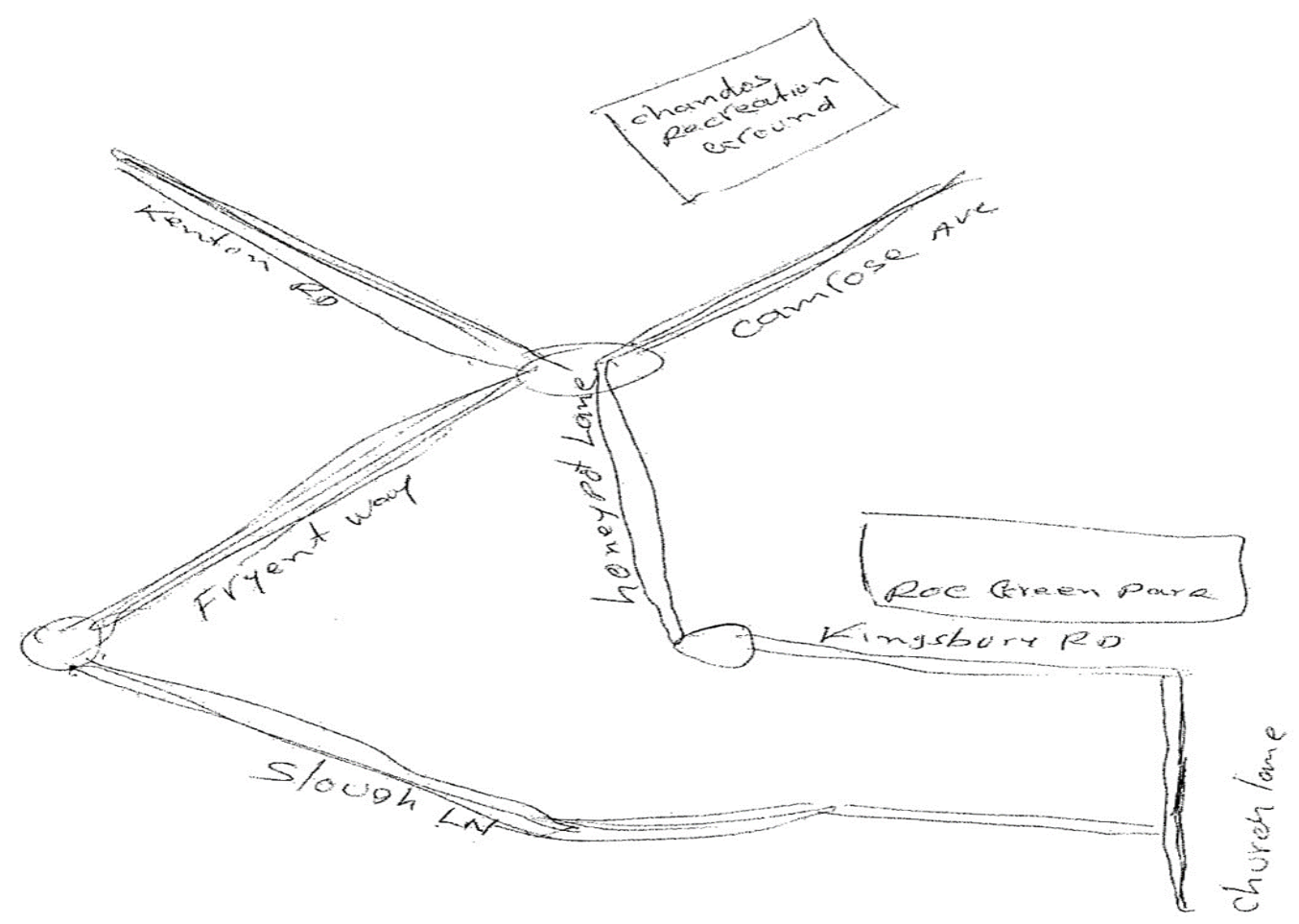

Figure 6: A hand-drawn map by Premji indicating one of his usual walking routes. 


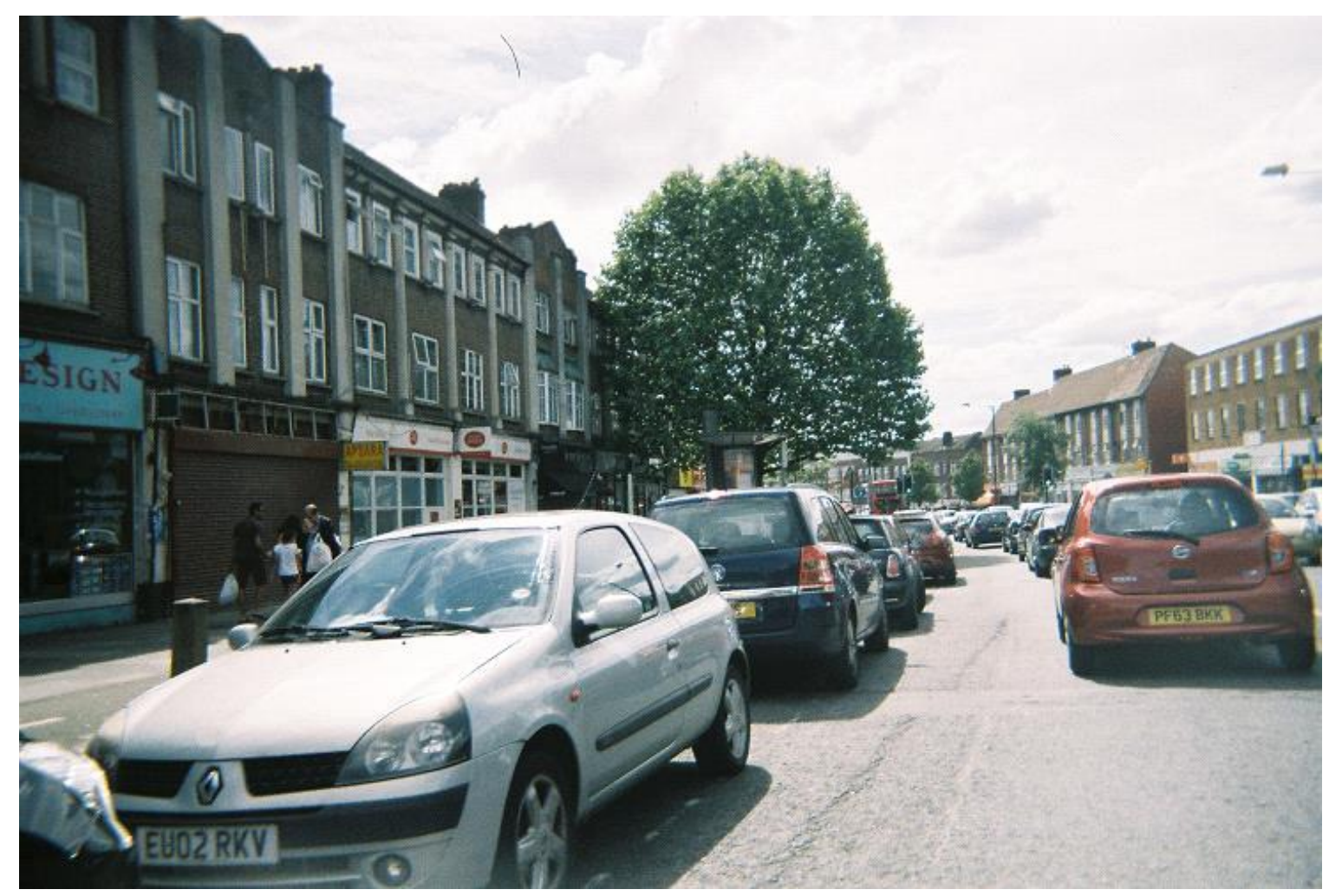

Figure 7. A photo taken by Premji at the start of his journey to his daughters' house

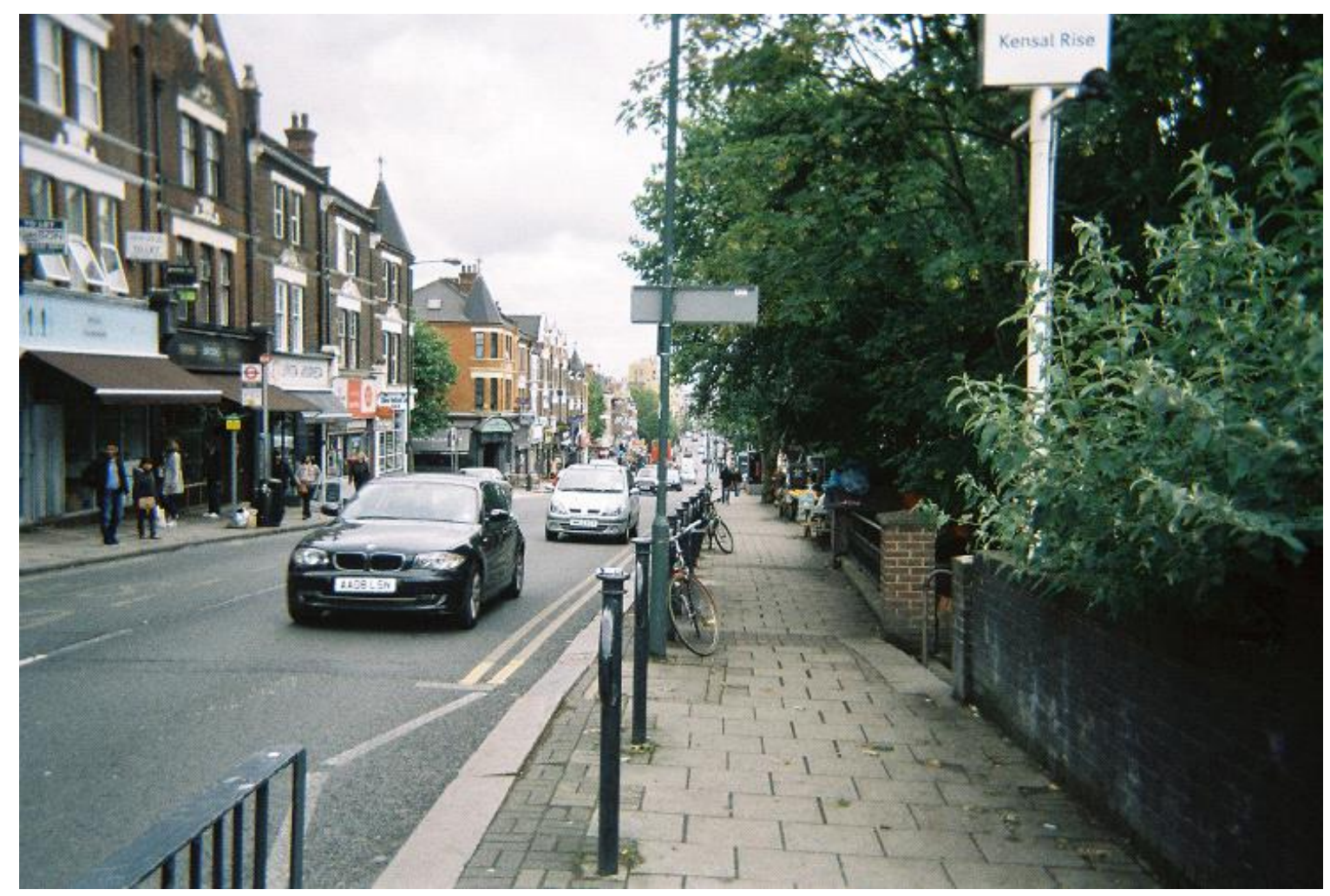

Figure 8. Walking around the area where his son's dentist clinic is located 


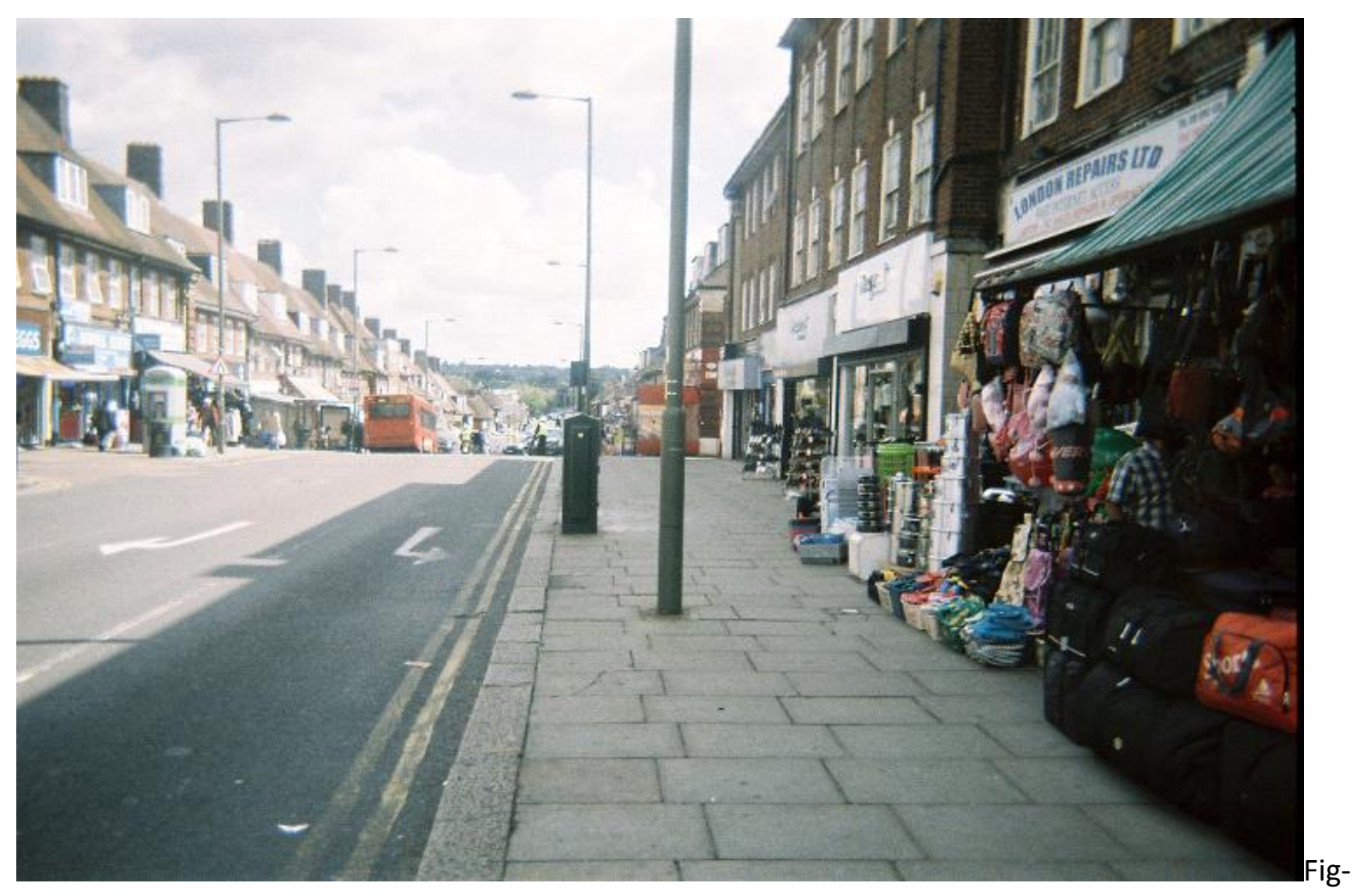

ure 9: Luxs' photo of convenience stores selling cheap goods across both sides of the road.

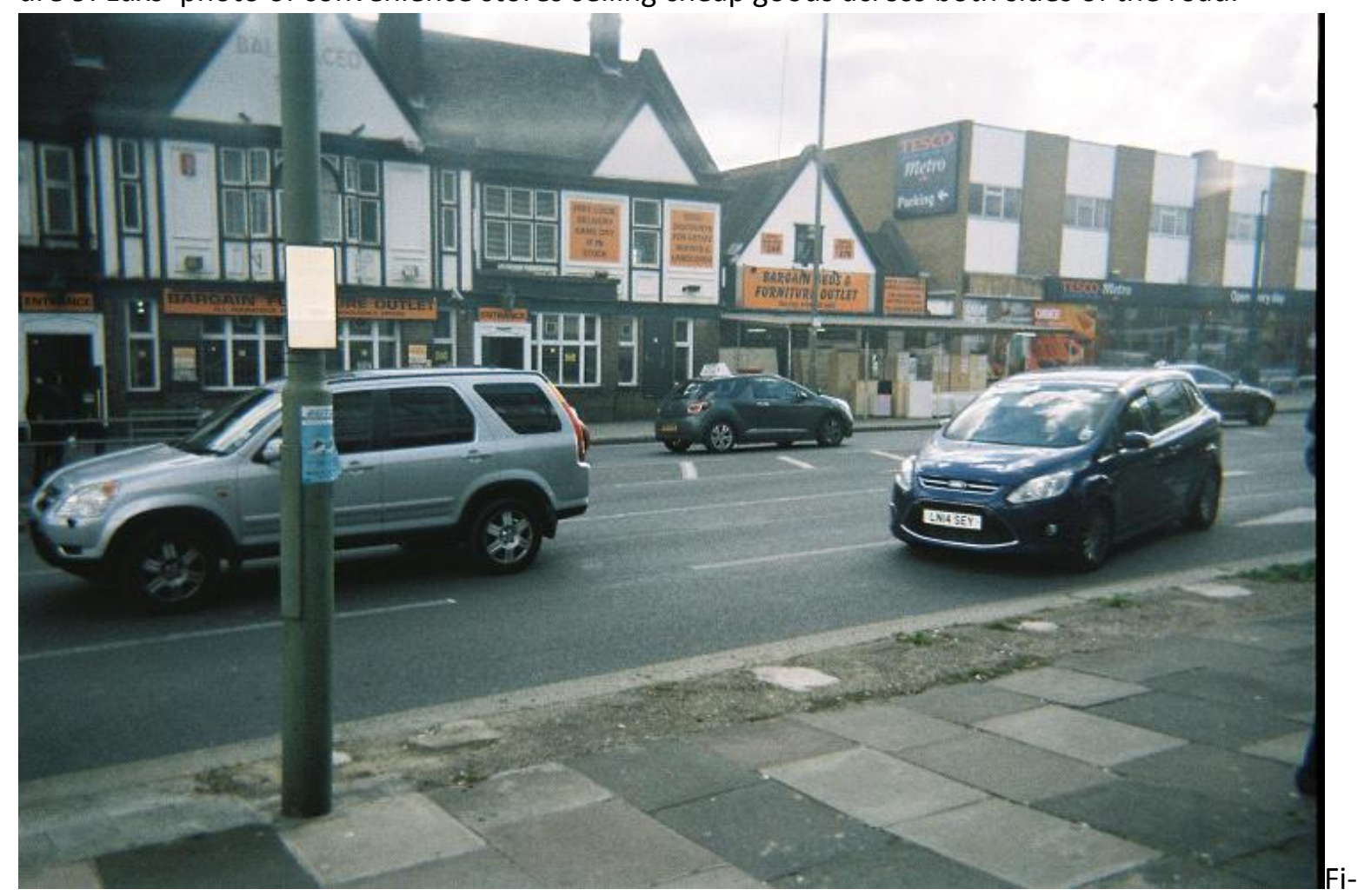

gure 10: Luxs' photo showing a former pub taken-over and extended, selling cheap bedroom furniture with boxes of goods spilling out onto the pavement. 